\title{
Indicator of Facility Performance Evaluation (FPE) for Educational Facilities of BTL Projects
}

\author{
Kwan-Jong Lee, Chun-Kyong Lee and Tae-Keun Park \\ Master's Candidate, Architectural Engineering Dep't of Mokwon University \\ General Manager, Technology Institute of LCCKOREA, Co., Ltd, Corresponding Author \\ Professor, Architectural Engineering Dep't of Mokwon University
}

http://dx.doi.org/10.5659/AIKAR.2012.14.1.35

\begin{abstract}
Build-Transfer-Lease (BTL) was introduced to the domestic construction market in 2005. Now, seven years later, the BTL model is most active for educational facilities. In 2011, 93 educational facility projects entered the maintenance stage. Considering the characteristics of today's BTL projects for educational facilities, the main issues are the initial performance and maintenance of educational facilities and the service-providing status for the 20-year operational management period, in relation to providing safety and convenience to students, the facility users. Seeking a solution, local education offices and departments in charge of BTL under the Ministry of Education, Science, and Technology have been exploring various methods of evaluating operational maintenance performance from various perspectives. For educational facility BTL projects, however, the appropriateness of initial operation performance evaluation, rather than considering the 20-year operational management period, is controversial in regards to sustainability. On this account, performance evaluation items in four areas-operational maintenance evaluation, facility performance status evaluation, maintenance subject evaluation, and sustainable change response evaluation-should be extracted. An indicator of facility performance evaluation is presented in this study through an AHP survey targeting experts, as part of establishing an operation performance evaluation system for educational facility BTL projects.
\end{abstract}

Keywords: Indicator of Facility Performance Evaluation, Operation Performance, BTL Project, Educational Facility

\section{INTRODUCTION}

Since the introduction of BTL to the domestic construction market, BTL projects, now facing their seventh year of execution, have been most active in the area of educational facilities, and about 93 educational facility projects reached the operational maintenance state as of the end of 2010. Furthermore, as projects for remodeling decrepit private school facilities (in addition to elementary and middle schools) have been included in the scope

Corresponding Author: Chun-Kyong Lee, General Manager Technology Institute of LCCKOREA, Co., Ltd 409 2Dong Banpo Shoppingtown Jamwon-dong, Seocho-gu, Seoul, 75-14, Korea

Tel :+82 2537 7616 7 e-mail : bri1305@gmail.com

This research was supported by Woman Researcher Program \& Experienced Researcher Program through the National Research Foundation (NRF) of Korea (2011-0015010 \& 2011-0000101) funded by the Ministry of Education, Science and Technology.

This is an Open Access article distributed under the terms of the Creative Commons Attribution Non-Commercial License (http://creativecommons. org/licenses/by-nc/3.0/) which permits unrestricted non-commercial use, distribution, and reproduction in any medium, provided the original work is properly cited. of BTL projects since the end of 2010 , the scale of the project is expected to increase. Considering the number of educational facility BTL projects in process, a study of sustainability in regards to operational maintenance is required.

Moreover, taking the specialized nature of educational facilities into account, the main issues are the initial performance and maintenance of educational facilities and the service-providing status in the 20-year operational management period, in relation to providing safety and convenience to students, who are the facility users. To this end, local education offices and departments in charge of BTL under the Ministry of Education, Science, and Technology have attempted various methods of evaluating operational maintenance performance. However, controversy has consistently arisen concerning the appropriateness of initial operation performance evaluation in regards to the sustainability of facilities.

For this reason, indicators of facility performance evaluation that consider sustainability will be presented in this study, as a part of establishing an operation performance evaluation system for educational facility BTL projects.

To develop an indicator of facility performance evaluation, domestic educational facility indicators and performance evaluation methods were considered in this study; on the basis of these, sustainable facility performance evaluation items were derived. In addition, performance indicators of existing BTL 
projects and educational facilities were analyzed, and sustainability was considered in order to establish the indicator of facility performance evaluation. To do this, key items including operational maintenance, maintenance subject evaluation, and environmental sustainability were extracted, and an AHP survey targeting experts was conducted. The sustainable indicator of facility performance evaluation is the result of considering the overall project processes and project follow-up of BTL projects, and it has the purpose of building qualitative and quantitative facility performance evaluation items and indicators in order to introduce an efficient operation performance evaluation system.

\section{THEORETICAL CONSIDERATIONS}

\subsection{Current educational facility indicator ${ }^{1}$ (1) Definition of education indicator}

The education indicator in Korea is defined in Table 1 below, through the relationship of education statistics and the education indicator. Here, indicators are defined as figures or signs representing phenomenon or a specific idea.

Table 1. Definition of educational indicator

\begin{tabular}{|c|c|}
\hline Type & Description \\
\hline $\begin{array}{l}\text { Education } \\
\text { statistics }\end{array}$ & $\begin{array}{l}\text { Represent a specific education phenomenon as a single } \\
\text { figure (factorial statistics) }\end{array}$ \\
\hline \multirow{2}{*}{$\begin{array}{l}\text { Education } \\
\text { indicator }\end{array}$} & $\begin{array}{l}\text { Represent two or more factorial statistics as a relation of } \\
\text { arithmetic rules }\end{array}$ \\
\hline & $\begin{array}{l}\text { Statistical value representing various indicators that } \\
\text { indicate a specific education phenomenon as a } \\
\text { combination of consistent functional relations }\end{array}$ \\
\hline
\end{tabular}

\section{(2) OECD education indicator}

OECD education indicators (Table 2) are composed of education organization output and learning effects; financial/human resources invested in education; access to, participation in, and development of education; learning environment; and school organization. Each item includes 5 10 detailed indicators. This indicator is limited to education, but it includes no facility indicator corresponding to the educational environment.

\section{(3) Korea international education indicator}

The Korean international education indicator is composed of educational investment and output as the financial resources, teaching environment, international human resources, education output, performance, and economic effects (seven items), which are limited by education quality. Some items reflecting the education facility environment are included in different items, such as the teaching environment.

\subsection{Consideration of facility performance evaluation ${ }^{2}$}

\footnotetext{
${ }^{1}$ Tae-Keun Park et al., a study on establishment of the management outcome assessment system in BTL business for a public educational facility using facility performance indicator, Mokwon University, 2011.

${ }^{2}$ Facility management guide book, Japan FM promotion communication council (edition) Korea Facility Management academy (translation), 1998
}

\section{(1) Facility performance ${ }^{3}$ evaluation}

As it mentioned at table 1 , there are few definitions of facility performance in Korea educational development institute (KEDI) In this study, we defined the concept of facility performance as "assessment serviced from schools and educational facilities to students and users and their satisfaction for the quality of services in whole type of new construction projects".

Facility performance evaluation, which focuses on quality among the facility management (hereafter "FM") goals of quality, finance, and supply, provides the data that it determines construction status and it is one of the methods for systematic inspection and management. It is divided in various ways by facility performance evaluators, and it includes the POE (Post Occupancy Evaluation) method that is based on the architecture user's satisfaction and the ORBIT (Office Research into Building and Information Technology) method that combines user satisfaction and expert building evaluation.

Table 2. OECD education indicator system

\begin{tabular}{|c|c|}
\hline Area & Indicator \\
\hline \multirow{10}{*}{$\begin{array}{l}\text { Education } \\
\text { organization } \\
\text { output and } \\
\text { learning } \\
\text { effect }\end{array}$} & 1. Learning level for adults \\
\hline & $\begin{array}{l}\text { 2. Secondary education completion ratio and higher } \\
\text { education entrance ratio }\end{array}$ \\
\hline & 3. Higher education completion ratio \\
\hline & 4. Higher education completion and termination ratio \\
\hline & 5. Achievement level in science for 15 -year-old students \\
\hline & $\begin{array}{l}\text { 6. Parents' awareness level related to school courses and } \\
\text { science study }\end{array}$ \\
\hline & $\begin{array}{l}\text { 7. Parents' social and economic status and higher } \\
\text { education participation ratio }\end{array}$ \\
\hline & $\begin{array}{l}\text { 8. Relationship between labor market participation and } \\
\text { education level }\end{array}$ \\
\hline & 9. Economic benefit of education \\
\hline & 10. Attraction of educational investment \\
\hline \multirow{7}{*}{$\begin{array}{l}\text { Financial / } \\
\text { human } \\
\text { resources } \\
\text { invested in } \\
\text { education }\end{array}$} & 1. Education cost per student \\
\hline & $\begin{array}{l}\text { 2. Education cost for education organization compared } \\
\text { to DP(Draft Proposal) }\end{array}$ \\
\hline & $\begin{array}{l}\text { 3. Public and private investment scale for education } \\
\text { organization }\end{array}$ \\
\hline & 4. Total education cost \\
\hline & $\begin{array}{l}\text { 5. Scale of education spending and education subsidies } \\
\text { for higher education organization students }\end{array}$ \\
\hline & 6. Income and expenses of education \\
\hline & 7. Efficiency of resources used for education \\
\hline \multirow{5}{*}{$\begin{array}{c}\text { Access to, } \\
\text { participation } \\
\text { in, and } \\
\text { development } \\
\text { of education }\end{array}$} & $\begin{array}{l}\text { 1. Participation ratio of elderly people in occupational } \\
\text { education programs }\end{array}$ \\
\hline & 2. School attendance ratio \\
\hline & 3. Studying abroad, and countries for overseas study \\
\hline & 4. Success rate in the transition from study to occupation \\
\hline & $\begin{array}{l}\text { 5. Rate of adult participation in educational training } \\
\text { during employment }\end{array}$ \\
\hline \multirow{6}{*}{$\begin{array}{c}\text { Learning } \\
\text { environment } \\
\text { and school } \\
\text { organization }\end{array}$} & 1. Class hours for each level of school \\
\hline & 2. Number of students per teacher and per class \\
\hline & 3. Teachers' pay level \\
\hline & 4. Teachers' class hours \\
\hline & $\begin{array}{l}\text { 5. Evaluation measuring method used in the education } \\
\text { system }\end{array}$ \\
\hline & 6. Decision-making level in the education system \\
\hline
\end{tabular}

${ }^{3}$ The author defined the concept of facility performance directly and additionally organized the facility condition assessment and the sustainable change response assessment based on the existing management outcome assessment. 


\section{(2) Required conditions in facility performance}

Regarding the aspects of required conditions in facility performance of FM, physical performance items such as size, power, and air conditioning capacity, the number of elevators or their frequency of operation, maintenance costs, and operational costs and performance values combined with many conditions, such as the psychological and conscious satisfaction of facility users or social, local, and environmental functions, are evaluated. In addition, the relationships between various costs or service indicators need to be analyzed from the organization's point of view, and the person in charge of application needs to conduct a performance evaluation in consideration of the relationships among such aspects of facility performance.

\section{(3) Comparison with facility performance evaluations}

Table 3. Comparison with facility performance evaluations

\begin{tabular}{c|l}
\hline \multicolumn{1}{c|}{ Type } & \multicolumn{1}{c}{ Description } \\
\hline WHO report & $\begin{array}{l}\text {-"Base of Healthy Residential Environment" report } \\
\text { published by the residential sanitation committee of } \\
\text { the WHO (World Health Organization) } \\
\text {-Items: safety, health, convenience, pleasantness (four } \\
\text { items) }\end{array}$ \\
\hline
\end{tabular}

-Pleasantness: It is often said that pleasantness "can be recognized but is hard to define." It does not simply refer to one characteristic but to the synthetic of Pleasantness multiple values

/health -Health: In the chart established when the WHO was organized this is referred to as not merely freedom from disease or disability but also physical, mental, and social well-being.

\begin{tabular}{|c|c|}
\hline $\begin{array}{l}\text { (Japan) } \\
\text { facility } \\
\text { performance } \\
\text { evaluation }\end{array}$ & $\begin{array}{l}\text {-Evaluation subject: A checklist with which an overall } \\
\text { evaluation is made, with a sum of scores determined by } \\
\text { researchers in universities for each item } \\
\text {-Stabilization: Performance evaluation stabilized } \\
\text { through discussions in architecture magazines or } \\
\text { papers about the performance itself or the difference } \\
\text { between performance and design and about the } \\
\text { purpose of performance evaluation }\end{array}$ \\
\hline
\end{tabular}

-Site, including the building (facility site conditions, type of ownership, lease and rental conditions, operation methods, etc.)

-Building facility (power, cabling, care for the disabled,

\begin{tabular}{l|l} 
Main & energy-saving plan, disaster prevention, safety, etc.) \\
target & -Indoor environment (light, sound, plants, art, etc.)
\end{tabular} -Space (area allocation, etc.)

-Workplace (recommended workplace status, layout style)

-Furniture/fixtures (furniture, fixtures, partitions, etc.)

\section{DERIVING AND VERIFYING FACILITY PERFORMANCE EVALUATION ITEMS}

\subsection{Deriving performance evaluation items (plan)}

In deriving facility performance evaluation items over two phase, the first items were derived based on the evaluation criteria of requirements and on key effect factors extracted from the basic research process for current BTL projects.

- Operation plan and practice evaluation: proper activity practice status, service level, management level, etc. according to operation plan

- Operation status evaluation: indicating through performance and status evaluation for facility maintenance activity, key facilities and plants, and status evaluation

- Process evaluation: determine activity practice status according to the job manual and the acceptability of critical activities

- Satisfaction evaluation between subjects: qualitative evaluation of subjective opinions, such as mutual satisfaction between user and manager and satisfaction with the action taken in regards to operational management

- Task achievement performance evaluation: evaluating, monitoring, and inspecting the performance of critical tasks generated by the operational management process

- Profile management and utilization evaluation: utilization of the results of existing activity practices, profile information management, etc.

The second deriving phase introduces sustainability and the ability to respond to change; some items were modified and complemented, but the existing first items were maintained to the extent possible. Operation/maintenance evaluation and maintenance subject evaluation are subdivided and matched with existing operation performance evaluation items, and connectivity with the rapidly changing educational environment is considered by adding facility performance evaluation and sustainable change response evaluation.

- Operation and maintenance evaluation : plan, practice and evaluation of operation/maintenance

- Facility performance/status evaluation: key structure unit/finishing status, facility performance of critical facilities by work type, evaluation of the environment cleanliness, etc.

- Maintenance subject evaluation: satisfaction evaluation by maintenance subject for facility users, authorities in charge, and the operational company.

- Sustainable change response evaluation: evaluation of the ability to respond to the rapidly changing education environment

Considering the characteristics of the public educational facility BTL project, problems related to facility performance/status evaluation resulting from physical deterioration that requires measures beyond consistent operational maintenance activities will inevitably occur after 10 years. Therefore, as shown in the figure, the availability of the facility after the BTL project period needs to be considered, and this usefulness should be applied to the facility performance/status evaluation. 


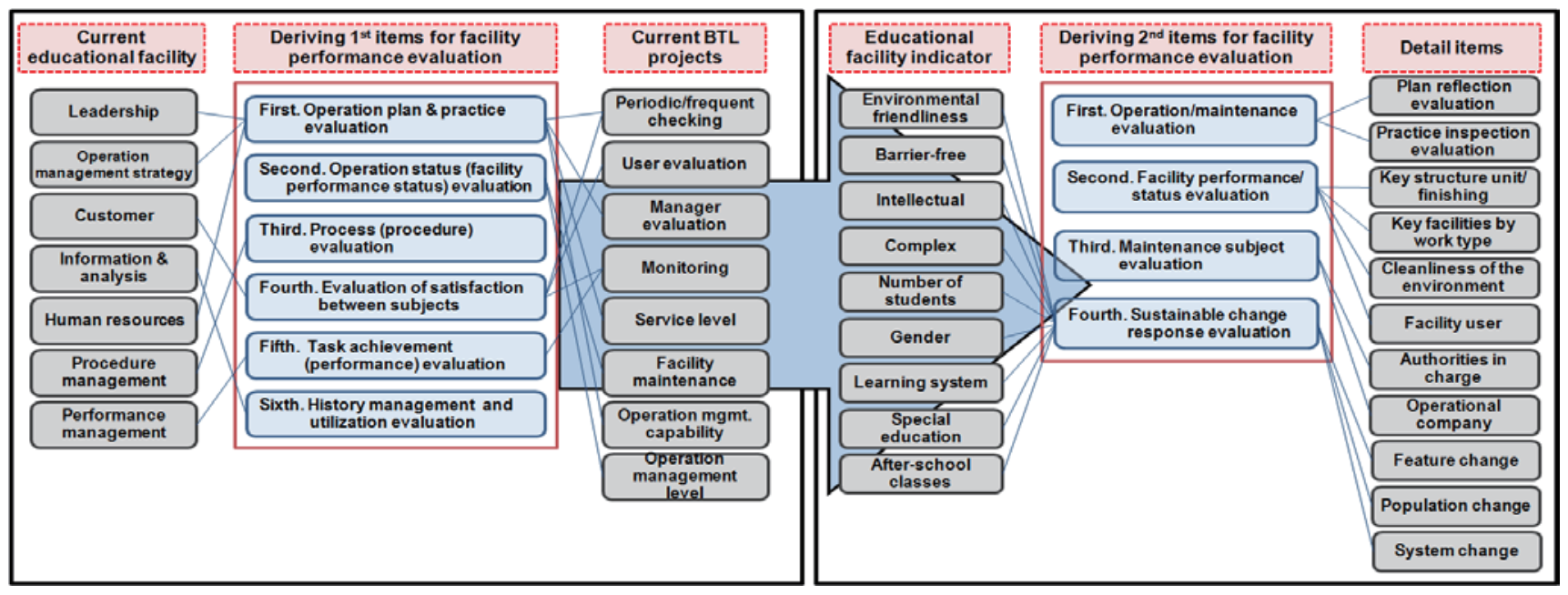

Figure 1. Facility performance evaluation items in BTL projects: extraction of first and second times

\subsection{Deriving detailed items for facility performance evaluation}

For facility performance evaluation items, step 1 was divided into four items: operation/maintenance evaluation, facility performance/status evaluation, maintenance subject evaluation, and sustainable change response evaluation. For each evaluation item, detailed evaluation factors were composed for steps $2 \sim 4$.

\section{(1) Operational maintenance evaluation}

Operation/maintenance evaluation can be divided into evaluation of how the plan is reflected and practical inspection and evaluation; the evaluation of how the plan is reflected, according to the evaluation factors, is divided into an operation management plan and a maintenance plan. Practical inspection and evaluation is divided into operation/maintenance practices and inspection and evaluation. Detailed evaluation factors are presented in Table 4.

Table 4. Detailed factors of operational maintenance evaluation

\begin{tabular}{|c|c|c|}
\hline Evaluation & $\begin{array}{l}\text { Evaluation } \\
\text { factor }\end{array}$ & Detailed evaluation factors \\
\hline \multirow{14}{*}{$\begin{array}{c}\text { Plan } \\
\text { reflection } \\
\text { evaluation }\end{array}$} & \multirow{7}{*}{$\begin{array}{l}\text { Operation } \\
\text { management } \\
\text { plan }\end{array}$} & Operational management practice capability \\
\hline & & Operational cost-saving plan \\
\hline & & Integrated management plan \\
\hline & & Operational management monitoring plan \\
\hline & & Safety and disaster prevention plan \\
\hline & & Cleaning and environmental sanitation plan \\
\hline & & Operational manager manpower plan \\
\hline & \multirow{7}{*}{$\begin{array}{l}\text { Maintenance } \\
\text { plan }\end{array}$} & Maintenance practice capability \\
\hline & & Operational cost-saving plan \\
\hline & & Integrated facility management plan(in BAS) \\
\hline & & $\begin{array}{l}\text { Maintenance plan (including the latest } \\
\text { construction methods and facility devices) }\end{array}$ \\
\hline & & Maintenance monitoring plan \\
\hline & & Facility safety plan \\
\hline & & $\begin{array}{l}\text { Appropriateness of Value engineering(VE) } \\
\text { and LCC(Life Cycle Cost) analysis }\end{array}$ \\
\hline
\end{tabular}

Table 4. Detailed factors of operational maintenance evaluation (Continued)

\begin{tabular}{|c|c|c|}
\hline Evaluation & $\begin{array}{c}\text { Evaluation } \\
\text { factor }\end{array}$ & Detailed evaluation factors \\
\hline \multirow{8}{*}{$\begin{array}{c}\text { Inspection } \\
\text { and } \\
\text { evaluation } \\
\text { practices }\end{array}$} & \multirow{5}{*}{$\begin{array}{c}\text { Operation/ } \\
\text { maintenance } \\
\text { practices }\end{array}$} & $\begin{array}{l}\text { Task fulfillment status } \\
\text { compared to operational maintenance plan }\end{array}$ \\
\hline & & Suitability of managing staff allocation \\
\hline & & Daily activity record and its correctness \\
\hline & & $\begin{array}{l}\text { Task fulfillment status } \\
\text { compared to monthly/quarterly report }\end{array}$ \\
\hline & & Actions taken for the matters pointed out \\
\hline & \multirow{3}{*}{\begin{tabular}{|c|} 
Operation/ \\
maintenance \\
inspection \\
and evaluation
\end{tabular}} & $\begin{array}{l}\text { Task fulfillment status } \\
\text { compared to operation/maintenance plan }\end{array}$ \\
\hline & & Performance evaluation check and inspection \\
\hline & & Performance evaluation assessment \\
\hline
\end{tabular}

\section{(2) Facility performance/status evaluation}

This is an evaluation factor that involves an inspection of the facility status of key structure units and finishing states in a building and of critical facilities for each work type, including mechanical facilities, communication/ electric systems, and firefighting facilities. Detailed evaluation factors are presented in Table 5.

\section{(3) Maintenance subject evaluation}

Prevention and follow-up for facility and environment are the same evaluation factors in satisfaction evaluation of the maintenance subjects of the facility user, the authorities in charge, and the operating company. In particular, the authorities in charge present an evaluation action item that allows action to be taken after the evaluation inspection of the facility user and the operating company.

Table 5. Detailed factors for facility performance/status evaluation

\begin{tabular}{c|c|c}
\hline Evaluation & $\begin{array}{c}\text { Evaluation } \\
\text { factor }\end{array}$ & \multicolumn{1}{c}{ Detailed evaluation factors } \\
\hline \multirow{2}{*}{$\begin{array}{c}\text { Key } \\
\text { structural } \\
\text { finishing }\end{array}$} & Structure & $\begin{array}{l}\text { Status of main internal structure units } \\
\text { 1) ceiling 2) floor 3) wall 4) stairs }\end{array}$ \\
\cline { 3 - 3 } & & $\begin{array}{l}\text { Status of main external structure units } \\
\text { 1) rooftop 2) outer wall 3) fence }\end{array}$ \\
\hline
\end{tabular}


Table 5. Detailed factors for facility performance/status evaluation (Continued)

\begin{tabular}{c|c|c}
\hline Evaluation & $\begin{array}{c}\text { Evaluation } \\
\text { factor }\end{array}$ & \multicolumn{1}{c}{ Detailed evaluation factors } \\
\hline \multirow{4}{*}{$\begin{array}{c}\text { Key } \\
\text { structural } \\
\text { finishing }\end{array}$} & \multirow{5}{*}{ Finishing } & $\begin{array}{l}\text { Status of internal finishing materials mgt. } \\
\text { 1) ceiling 2) floor 3) wall } \\
\text { 4) windows 5) stairs }\end{array}$ \\
\cline { 3 - 3 } & & $\begin{array}{l}\text { Status of exterior finishing materials mgt. } \\
\text { 1) rooftop 2) outer wall 3) floor } \\
\text { 4) windows 5) stairs }\end{array}$ \\
\cline { 3 - 3 } & & $\begin{array}{l}\text { Additional facilities mgt. } \\
\text { 1) fitness equipment (facilities) } \\
\text { 2) various work structures }\end{array}$ \\
\hline
\end{tabular}

Status of elevator and dump water facility mgt.

Proper role of heating insulation

Status of organization according to usage purpose

1) mechanical room 2) electric room

3) broadcasting room

Mechanical Noise, vibration, and operational status of facility equipment

1) air blower 2) pump 3) freezer

4) air conditioner (rotary equipment)

5) piping 6) ducts

Control setting and actual status of diverse control equipment, manager's understanding of control systems

Management status according to regulations related to the gas facility
Key facility by work type

Electric/ communicat ion system facility facility, emergency light for shelter)

Operational status of firefighting facilities

(self detection, warning alarm, fireplug, water spray, connective watering, etc.)

Cleaning status

1) toilet 2) floor 3) wall body

Cleaning status

1) entrance 2) corridor 3) stairs

Cleaning status

1) special classroom 2) management room

3) other rooms

Cleaning status

1) equipment 2) piping

and

environment al sanitation
Cleaning
Cleaning status
1) rooftop 2) drainage hole

3) playground drain way

Cleaning status

1) playground 2) outdoor space

Cleaning status

1) outer wall 2) external windows and doors

Cleaning and management status

1) dumping ground

\begin{tabular}{|c|l}
\hline \multirow{5}{*}{ Sanitation } & $\begin{array}{l}\text { Status of the implementation of preventive } \\
\text { measures (sterilization, killing insects and } \\
\text { rats) required by disease control organizations, } \\
\text { authorities in charge, or the school }\end{array}$ \\
\cline { 2 - 3 } & $\begin{array}{l}\text { Implementation status of cleaning and } \\
\text { sterilization according to the work plan }\end{array}$ \\
\cline { 2 - 3 } $\begin{array}{c}\text { Disaster } \\
\text { prevention }\end{array}$ & $\begin{array}{l}\text { Safety inspection and disaster prevention plan } \\
\text { 1) mechanical facility 2) electricity/ } \\
\text { communication 3) fire extinguishing facility }\end{array}$ \\
\hline \multirow{2}{*}{ Safety } & $\begin{array}{l}\text { Facility monitoring/facility monitoring by } \\
\text { work type (IBS, etc.)/monitoring by bundling } \\
\text { schools }\end{array}$ \\
\cline { 2 - 3 } & $\begin{array}{l}\text { Negligence related to risk factors at facilities } \\
\text { near the school }\end{array}$ \\
\hline
\end{tabular}

Table 6. Detailed factors for maintenance subject evaluation

\begin{tabular}{|c|c|c|}
\hline Evaluation & $\begin{array}{l}\text { Evaluation } \\
\text { factor }\end{array}$ & Detailed evaluation factors \\
\hline \multirow{8}{*}{ Facility user } & \multirow{4}{*}{$\begin{array}{l}\text { Prevention: } \\
\text { facility }\end{array}$} & $\begin{array}{l}\text { Facility management suitable for } \\
\text { an educational environment } \\
\text { 1) buildings, structures, attachments }\end{array}$ \\
\hline & & Availability of indoor facilities \\
\hline & & Facility maintenance \\
\hline & & Facility manager's training status \\
\hline & \begin{tabular}{|c|} 
Prevention: \\
environment
\end{tabular} & $\begin{array}{l}\text { Environment management suitable for } \\
\text { an educational environment } \\
\text { 1) temperature 2) illumination } \\
\text { 3) sanitation (cleaning status) 4) water supply } \\
\text { (water supply, warm water, drainage) } \\
\text { 5) power 6) gas }\end{array}$ \\
\hline & \multirow{3}{*}{ Follow-up } & Inspection and quick service response \\
\hline & & $\begin{array}{l}\text { Satisfaction with the receipt and processing of } \\
\text { reports of inconvenience }\end{array}$ \\
\hline & & $\begin{array}{l}\text { Quick replacement } \\
\text { When abnormal function is reported. }\end{array}$ \\
\hline \multirow{12}{*}{$\begin{array}{l}\text { Authorities } \\
\text { in charge }\end{array}$} & \multirow{4}{*}{$\begin{array}{l}\text { Prevention: } \\
\text { facility }\end{array}$} & $\begin{array}{l}\text { Facility management suitable for } \\
\text { an educational environment } \\
\text { 1) buildings, structures, attachments }\end{array}$ \\
\hline & & Availability of indoor facilities \\
\hline & & Facility maintenance \\
\hline & & Facility manager's training status \\
\hline & \multirow{6}{*}{$\begin{array}{c}\text { Prevention: } \\
\text { environment }\end{array}$} & Activity report \\
\hline & & Plan for the provision of other services \\
\hline & & Reflection of cultural features \\
\hline & & Plan to satisfy social functions \\
\hline & & Plan to satisfy user demand \\
\hline & & User convenience and safety \\
\hline & \begin{tabular}{|c|} 
Corrective \\
maintenance
\end{tabular} & Inconvenience reporting and record \\
\hline & $\begin{array}{l}\text { Evaluation } \\
\text { action }\end{array}$ & $\begin{array}{l}\text { Action taken after the evaluation and } \\
\text { inspection of facility user and operating } \\
\text { company }\end{array}$ \\
\hline \multirow{8}{*}{$\begin{array}{l}\text { Operational } \\
\text { company }\end{array}$} & \multirow{4}{*}{$\begin{array}{l}\text { Prevention: } \\
\text { facility }\end{array}$} & $\begin{array}{l}\text { Facility management suitable for } \\
\text { an educational environment } \\
\text { 1) buildings, structures, attachments }\end{array}$ \\
\hline & & Availability of indoor facilities \\
\hline & & Facility maintenance \\
\hline & & Facility manager's training status \\
\hline & \multirow{4}{*}{$\begin{array}{c}\text { Prevention: } \\
\text { environment }\end{array}$} & Activity report \\
\hline & & Services provided, method, practicing plan \\
\hline & & $\begin{array}{l}\text { Action to reduce energy costs in building } \\
\text { (Proper lighting, water leakage, etc.) }\end{array}$ \\
\hline & & Environmental sanitation and cleaning plan \\
\hline
\end{tabular}


Table 6. Detailed factors for maintenance subject evaluation (Continued)

\begin{tabular}{|c|c|c|}
\hline Evaluation & $\begin{array}{l}\text { Evaluation } \\
\text { factor }\end{array}$ & Detailed evaluation factors \\
\hline \multirow{6}{*}{$\begin{array}{l}\text { Operational } \\
\text { company }\end{array}$} & \begin{tabular}{c|} 
Prevention: \\
environment
\end{tabular} & $\begin{array}{l}\text { Environmental management suitable for an } \\
\text { educational environment } \\
\text { 1) temperature 2) illumination } \\
\text { 3) sanitation (cleaning status) } \\
\text { 4) water supply (water supply, warm water, } \\
\text { drainage) 5) power 6) gas }\end{array}$ \\
\hline & \multirow{3}{*}{$\begin{array}{l}\text { Prevention: } \\
\text { safety } \\
\text { management }\end{array}$} & Monitoring implementation plan \\
\hline & & $\begin{array}{l}\text { Attire and attitude of security personnel, } \\
\text { outsider access control after school, and proper } \\
\text { school management during holidays }\end{array}$ \\
\hline & & $\begin{array}{l}\text { Practicing given job regulations, including lock } \\
\text { system check and patrol }\end{array}$ \\
\hline & \multirow[t]{2}{*}{$\begin{array}{l}\text { Corrective } \\
\text { maintenance }\end{array}$} & $\begin{array}{l}\text { Appropriate action in the event of power } \\
\text { failure and water cut-off (secure emergency } \\
\text { generator, water supply, etc.) }\end{array}$ \\
\hline & & Process of inconvenience reporting and record \\
\hline
\end{tabular}

\section{(4) Sustainable change response evaluation}

In the sustainable change response evaluation, evaluation factors reflect the perspective of long-term operational maintenance.

Table 7. Detailed factors for sustainable change response evaluation

\begin{tabular}{|c|c|c|}
\hline Evaluation & $\begin{array}{l}\text { Evaluation } \\
\text { factor }\end{array}$ & Detailed evaluation factors \\
\hline \multirow{9}{*}{$\begin{array}{l}\text { Feature } \\
\text { change }\end{array}$} & \multirow{2}{*}{$\begin{array}{c}\text { Environmental } \\
\text { friendliness }\end{array}$} & Status of renewable energy utilization \\
\hline & & $\begin{array}{l}\text { Eco-friendly environment } \\
\text { (Temperature, humidity, light, water, etc.) }\end{array}$ \\
\hline & \multirow{2}{*}{ Barrier-free } & Utilization ratio compared to the design \\
\hline & & Consider availability \\
\hline & \multirow{3}{*}{ Intelligence } & Ubiquitous education environment \\
\hline & & Introduce building mgmt. automation system \\
\hline & & Automate school administration \\
\hline & \multirow{2}{*}{ Complex } & $\begin{array}{l}\text { Space shared with local residents } \\
\text { (Parking lot, playground, etc.) }\end{array}$ \\
\hline & & Provide complex facilities, etc. \\
\hline \multirow{4}{*}{$\begin{array}{l}\text { Population } \\
\text { change }\end{array}$} & \multirow{3}{*}{$\begin{array}{l}\text { Number of } \\
\text { students }\end{array}$} & $\begin{array}{l}\text { Room allocation according to declining } \\
\text { population }\end{array}$ \\
\hline & & Change and utilization of other facilities \\
\hline & & Utilize special classrooms, etc. \\
\hline & Gender & $\begin{array}{l}\text { Change room allocation } \\
\text { (Toilet, women's lounge, etc.) }\end{array}$ \\
\hline \multirow{7}{*}{$\begin{array}{l}\text { System } \\
\text { change }\end{array}$} & \multirow{2}{*}{$\begin{array}{l}\text { Learning } \\
\text { system }\end{array}$} & $\begin{array}{l}\text { Training course change } \\
\text { (Seventh training course, etc.) }\end{array}$ \\
\hline & & $\begin{array}{l}\text { Teaching method change } \\
\text { (Ubiquitous mode, electronic materials, etc.) }\end{array}$ \\
\hline & \multirow{3}{*}{$\begin{array}{c}\text { Special } \\
\text { education }\end{array}$} & $\begin{array}{l}\text { Facility management for the disabled } \\
\text { (Ramps, etc.) }\end{array}$ \\
\hline & & Relaxation and welfare facilities \\
\hline & & Special programs, etc. \\
\hline & \multirow{2}{*}{$\begin{array}{l}\text { After-school } \\
\text { classes }\end{array}$} & Supplement special classrooms \\
\hline & & $\begin{array}{l}\text { Arrange places for special training } \\
\text { (English towns, etc.) }\end{array}$ \\
\hline
\end{tabular}

For feature changes, approaches not only from existing ubiquitous technology development and complex facilities but also from the aspects of eco-friendliness, renewable energy utilization, and energy conservation are attempted, and characteristics of users are considered in terms of achieving a barrier-free structure. In addition, national demographic factors such as the low birth rate are considered. Factors for responding to school environment changes, including training course changes, special education, and after-school classes, are included.

\section{DEVELOP A SUSTAINABLE INDICATOR FOR FACILITY PERFORMANCE EVALUATION}

With the derived contents from the detailed items of facility performance evaluation presented above, weights of diverse facility performance evaluation factors were analyzed using the AHP (Analytic Hierarchy Process) method, and the indicator of facility performance evaluation was presented in order to eventually develop an operation performance evaluation system.

As a part of the operation performance evaluation system for current educational facility BTL projects, the accurate analysis of performance evaluation items in operation and maintenance should be a precondition for evaluating the acceptability of facility performance evaluation items and for preparing indicators. Accordingly, an attempt has been made to derive factors that affect operational maintenance performance evaluation and to analyze cause-and-effect relationships of individual factors by constructing a facility performance evaluation model.

\subsection{AHP survey overview and analysis \\ (1) Overview of AHP expert survey and analysis}

The AHP expert survey was conducted during two weeks, from September $20^{\text {th }}$ to October $1^{\text {st }}$ of 2010, via email. The survey targeted 30 people-authorities in charge, project participants (operational companies), and project evaluation members (professors, etc.) experienced in education facility BTL project operation and maintenance and performance evaluation were selected in advance to form a group of experts. In addition, detailed items were modified based on the results of extracting facility performance items for an operation performance evaluation based on the expert opinions given in this survey

- Survey overview

Table 8. AHP survey overview

\begin{tabular}{|c|c|}
\hline Type & Evaluation items \\
\hline Objective & $\begin{array}{l}\text { Derive facility performance indicator through acceptability } \\
\text { and weight evaluation for the operation performance } \\
\text { evaluation item of the education facility BTL project }\end{array}$ \\
\hline Targets & $\begin{array}{l}\text { Professors carrying out BTL-related research, individuals } \\
\text { and experts who have participated in the BTL project, and } \\
\text { hands-on work from the Korea Educational Development } \\
\text { Institute across the country }\end{array}$ \\
\hline Method & Survey distribution and collection through email \\
\hline Period & $\begin{array}{l}\text { Questionnaire distribution: Sep. } 20^{\text {th }}, 2010 \text { to Oct. } 1^{\text {st }}, 2010 \\
\text { Questionnaire analysis: Oct. } 11^{\text {th }}, 2010 \text { to Oct. } 25^{\text {th }}, 2010 \text { (two } \\
\text { weeks + two weeks) }\end{array}$ \\
\hline $\begin{array}{l}\text { Return } \\
\text { ratio }\end{array}$ & $\begin{array}{l}\text { Collected } 26 \text { copies of a total of } 30 \text { copies } \\
(87 \% \text { collection ratio, } 25 \text { copies analyzed })\end{array}$ \\
\hline
\end{tabular}




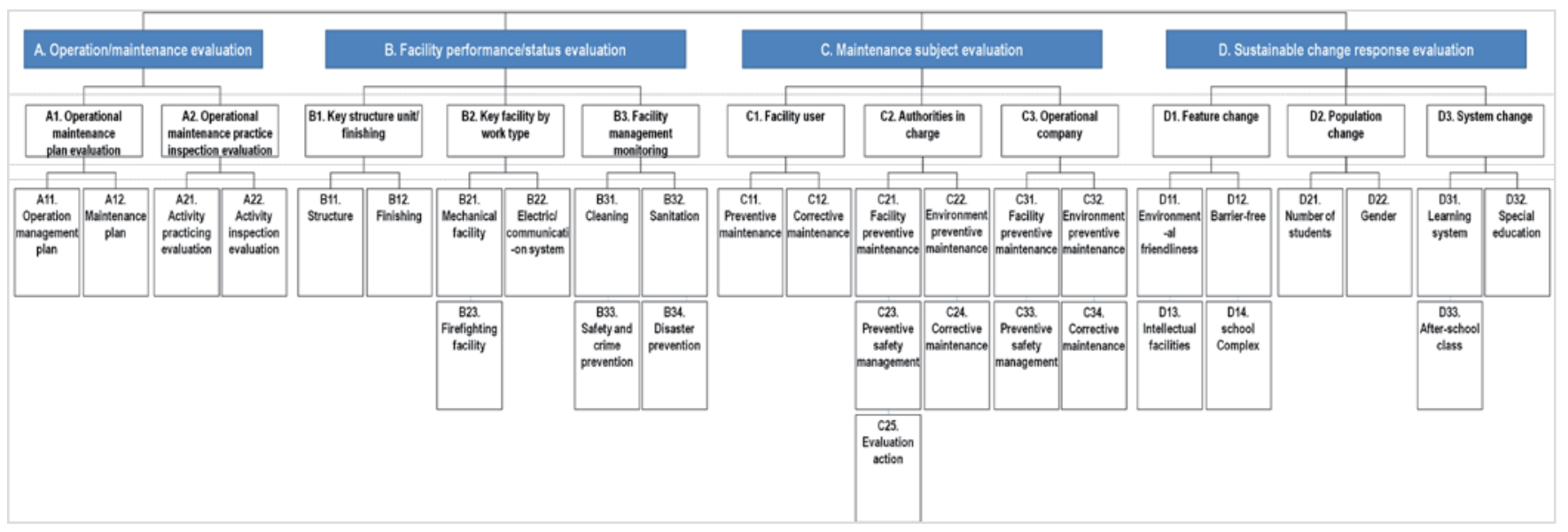

Figure 2. a AHP three-step hierarchical structure for the indicator of facility performance evaluation

Furthermore, survey request and questionnaire collection were conducted with 30 respondents, including experts who participated in the survey. Of 26 collected questionnaires, 25 were analyzed; that questionnaire was excluded ${ }^{4}$ on account of the consistency of the responses.

\section{(2) AHP hierarchical structure setting}

To develop the indicator of facility performance evaluation, a critical item in the operation performance evaluation system of the educational facility BTL project, the AHP analysis method was utilized. In addition, a hierarchy evaluation model for developing a sustainable indicator of facility performance evaluation was made and is displayed in the diagram.

The goal of evaluation is to derive the optimal items and indicators in order to determine the indicator of facility performance evaluation and operation performance evaluation items - that is, the factors in step 1 are divided into the following four items: operation/maintenance evaluation, facility performance/status evaluation, maintenance subject evaluation, and sustainable change response evaluation. Completion of the model was conducted through a computer program; Expert Choice 11 (EC 11), which was developed with the current AHP analysis tool, was used.

The hierarchical structure for the indicator of facility performance evaluation (operation performance evaluation item) in steps 1 3 of the educational facility BTL project is presented in Figure 2.

\subsection{Weighting analysis for each hierarchy}

Weights for each item were calculated by utilizing the AHP method, and the geometric average method composed of a single individual comparison matrix was used; in this method, the geometric averages of evaluation values from all evaluators are calculated and merged for each element in an individual comparison matrix prepared by the evaluator, and this is taken as an another element. ${ }^{5}$ In addition, indicator values were calculated

\footnotetext{
${ }^{4}$ In the weight calculation, if the consistency indicator (CI) is 0.1 or more or the inconsistency ratio (CR) is $10 \%$ or less, the respondent's survey result is considered unacceptable and is excluded from the calculation.

${ }^{5}$ There are three possible approaches to merging evaluation values from multiple evaluators in the AHP method when the reciprocal feature is required. Because a change may occasionally occur between final results, the
}

based on a total score of 1,000 , with a calculation formula of corresponding weights $\times$ total score.

\section{(1) Step 1}

By analyzing evaluation factors from the expert group through the AHP survey, the following weights were calculated in step 1. The corresponding weights were allocated.
A. Operation/maintenance evaluation: 0.312
B. Facility performance/status evaluation: 0.475
C. Maintenance subject evaluation: 0.115
D. Sustainable change response evaluation: 0.098

\section{(2) Step 2}

Through analysis of the weights of facility performance evaluation factors in step 2, a practice inspection evaluation item was calculated with a higher weight than that of the plan evaluation in A. operation/maintenance evaluation; weights were calculated for key structure units and finishing in B. facility performance/ status evaluation.

The weight of the operational company was calculated to be very low in C. maintenance subject evaluation, which may indicate that awareness of the importance of the operational company was insufficient. Moreover, a lower weight was allocated to D. sustainable change response evaluation than to other items, which may indicate that changes of the evaluation system were not adequate in relation to performance requirements.

\section{(3) Step 3}

In the analysis of the weights of facility performance evaluation in step 3, activity inspection and evaluation (0.124), key structure (0.119), activity practice evaluation (0.095), and key finishing (0.095) exhibit high weights; many items in maintenance subject evaluation and sustainable change response evaluation exhibit low weights.

geometric averaging method that most accurately maintains the AHP method was used. -The geometric average method (Aczel \& Saaty, 1983), which keeps the reciprocal feature in a matrix, obtains merged weights through numerical averaging with calculated weights and through geometrical averaging with calculated weights. 
Table 9. Facility performance indicator weighting analysis results

\begin{tabular}{|c|c|c|c|c|c|c|}
\hline Step 1 & Weight & Step 2 & Weight & Step 3 - Evaluation factor & Weight & $\begin{array}{l}\text { Indicator } \\
\text { value }\end{array}$ \\
\hline \multirow{4}{*}{$\begin{array}{l}\text { A. Operation/maintenance } \\
\text { evaluation }\end{array}$} & \multirow{4}{*}{0.312} & \multirow{2}{*}{$\begin{array}{l}\text { A-1. Plan (reflection) } \\
\text { evaluation }\end{array}$} & \multirow{2}{*}{0.093} & A-1-1. Operation management plan & 0.032 & 32 \\
\hline & & & & A-1-2. Maintenance plan & 0.061 & 61 \\
\hline & & \multirow{2}{*}{$\begin{array}{l}\text { A-2. Practice inspection and } \\
\text { evaluation }\end{array}$} & \multirow{2}{*}{0.219} & A-2-1. Activity practice evaluation & 0.095 & 95 \\
\hline & & & & A-2-2. Activity inspection and evaluation & 0.124 & 124 \\
\hline \multirow{9}{*}{$\begin{array}{l}\text { B. Facility performance/ } \\
\text { status evaluation }\end{array}$} & \multirow{9}{*}{0.475} & \multirow{2}{*}{$\begin{array}{l}\text { B-1. Key structural } \\
\text { unit/finishing }\end{array}$} & \multirow{2}{*}{0.214} & B-1-1. Structure & 0.119 & 119 \\
\hline & & & & B-1-2. Finishing & 0.095 & 95 \\
\hline & & \multirow{3}{*}{$\begin{array}{l}\text { B-2. Key facility by work } \\
\text { type }\end{array}$} & \multirow{3}{*}{0.168} & B-2-1. Mechanical facility & 0.059 & 59 \\
\hline & & & & B-2-2. Electric/communication system & 0.037 & 37 \\
\hline & & & & B-2-3. Firefighting facility & 0.072 & 72 \\
\hline & & \multirow{4}{*}{$\begin{array}{l}\text { B-3. Facility management } \\
\text { monitoring }\end{array}$} & \multirow{4}{*}{0.093} & B-3-1. Cleaning & 0.006 & 6 \\
\hline & & & & B-3-2. Sanitation & 0.017 & 17 \\
\hline & & & & B-3-3. Safety and crime prevention & 0.028 & 28 \\
\hline & & & & B-3-4. Disaster prevention & 0.042 & 42 \\
\hline \multirow{11}{*}{$\begin{array}{l}\text { C. Maintenance subject } \\
\text { evaluation }\end{array}$} & \multirow{11}{*}{0.115} & \multirow{2}{*}{ C-1. Facility user } & \multirow{2}{*}{0.061} & C-1-1. Preventive maintenance & 0.041 & 41 \\
\hline & & & & C-1-2. Corrective maintenance & 0.020 & 20 \\
\hline & & \multirow{5}{*}{ C-2. Authorities in charge } & \multirow{5}{*}{0.043} & C-2-1. Facility preventive maintenance & 0.009 & 9 \\
\hline & & & & C-2-2. Environment preventive maintenance & 0.017 & 17 \\
\hline & & & & C-2-3. Preventive safety management & 0.009 & 9 \\
\hline & & & & C-2-4. Corrective maintenance & 0.002 & 2 \\
\hline & & & & C-2-5. Evaluation action & 0.006 & 6 \\
\hline & & \multirow{4}{*}{ C-3. Operation company } & \multirow{4}{*}{0.011} & C-3-1. Facility preventive maintenance & 0.002 & 2 \\
\hline & & & & C-3-2. Environment preventive maintenance & 0.005 & 5 \\
\hline & & & & C-3-3. Preventive safety management & 0.003 & 3 \\
\hline & & & & C-3-4. Corrective maintenance & 0.001 & 1 \\
\hline \multirow{9}{*}{$\begin{array}{l}\text { D. Sustainable change } \\
\text { response evaluation }\end{array}$} & \multirow{9}{*}{0.098} & \multirow{4}{*}{ D-1. Feature change } & \multirow{4}{*}{0.045} & D-1-1. Environmental friendliness & 0.020 & 20 \\
\hline & & & & D-1-2. Barrier-free & 0.012 & 12 \\
\hline & & & & D-1-3. Intelligent facility & 0.005 & 5 \\
\hline & & & & D-1-4. School complex & 0.008 & 8 \\
\hline & & \multirow{2}{*}{ D-2. Population change } & \multirow{2}{*}{0.031} & D-2-1. Number of students & 0.019 & 19 \\
\hline & & & & D-2-2. Gender & 0.012 & 12 \\
\hline & & & & D-3-1. Learning system & 0.011 & 11 \\
\hline & & D-3. System change & 0.022 & D-3-2. Special education & 0.007 & 7 \\
\hline & & & & D-3-3. After-school classes & 0.004 & 4 \\
\hline & & Sum of facility performanc & dicators & average of 25 indicators) & & 1,000 \\
\hline
\end{tabular}

\subsection{Weighting analysis final result}

- Quantification of facility performance indicators

The indicator of facility performance evaluation for developing the operation performance evaluation system for an education facility BTL project is shown in Table 9. A more practical operation performance evaluation can be expected if this result is applied as evaluation criteria for operation performance evaluation.

\subsection{Deriving the priority of operation performance through the facility performance evaluation model}

This study attempted to derive operation performance priority for an educational facility BTL project by introducing facility performance indicators that consider sustainability in the operation performance evaluation stage. This formula is an evaluation model for the indicator of facility performance evaluation and suggests a priority-deriving formula.

$$
\begin{aligned}
& \text { BTLPEI }_{\mathrm{f}}=\mathrm{f}\left(\mathrm{A}_{\mathrm{i}}, \mathrm{A}_{\mathrm{j}}, \mathrm{A}_{\mathrm{k}}, \mathrm{A}_{\mathrm{l}} \cdots\right) \\
& \text { BTLPEI } i=(\text { OMA } i+\text { PCA } i+\text { OMUA } i+\mathrm{SCA} i)
\end{aligned}
$$

Where BTLPEI ${ }^{6}$ is related to

- $A_{\mathrm{i}}$ : Alternative Project i

- $\mathrm{OMA}_{\mathrm{i}}$ : Operation/Maintenance Analysis of Indicator): operation/ maintenance evaluation result value

- $\mathrm{PCA}_{\mathrm{i}}$ (Performance/Condition Analysis of Indicator): facility performance/status evaluation result value

- $\mathrm{OMUA}_{\mathrm{i}}($ Operation/Maintenance User Analysis of Indicator): maintenance subject evaluation result value

- $\mathrm{SCA}_{\mathrm{i}}$ (Sustainable Correspondence Analysis of Indicator): sustainable change response evaluation result value

In the weights and priority evaluation model derived earlier, while scoring standardization needs to be applied through the database $(\mathrm{DB})$ of each unit project, because standard indicators for evaluation by the facility project units of BTL projects were different, this processing was considered outside of the scope of this study owing to insufficient data.

\footnotetext{
${ }^{6}$ The Priority order of Performance Evaluation Indicator in BTL Projects
} 


\section{PILOT TEST TO VERIFY INDICATOR OF THE FACILITY PERFORMANCE EVALUATION}

Pilot tests were conducted on two projects that had been operated and maintained for five years. The results indicated that, for facility conditions among the four sub indicator items, both projects showed lower scores than had been shown in existing performance evaluations.

Table 10. Results of pilot tests conducted on two facility projects

\begin{tabular}{|c|c|c|}
\hline Type & $\begin{array}{l}\text { K elementary } \\
\text { School }\end{array}$ & $\begin{array}{c}\text { D elementary/middle } \\
\text { Schools }\end{array}$ \\
\hline \multirow{2}{*}{$\begin{array}{c}\text { existing } \\
\text { performance } \\
\text { evaluation } \\
\text { systems }\end{array}$} & 920 & 890 \\
\hline & \multicolumn{2}{|c|}{$\begin{array}{l}\text { +High service quality and user satisfaction } \\
+ \text { Appropriate maintenance was conducted } \\
+ \text { Few complaints(based on a full score of } 1000 \text { points) }\end{array}$} \\
\hline \multirow[b]{3}{*}{$\begin{array}{c}\text { New } \\
\text { performance } \\
\text { evaluation } \\
\text { systems }\end{array}$} & 887 & 794 \\
\hline & $\begin{array}{l}\text { Facility condition indicator } \\
\text { and a high score were given } \\
\text { in satisfaction evaluation }\end{array}$ & $\begin{array}{l}\text { No facility condition } \\
\text { indicator and } \\
\text { sustainability at all }\end{array}$ \\
\hline & \multicolumn{2}{|c|}{$\begin{array}{l}\text { +Facility condition indicators are somewhat low } \\
\text { +Sustainability has not been sufficiently considered } \\
\text { +For operating company evaluation, satisfaction with } \\
\text { works is high (Consciousness is somewhat insufficient) } \\
\text { +Since operating funds were insufficient, these schools } \\
\text { were concerned about facility conditions after the } \\
\text { eventual transfer of control. }\end{array}$} \\
\hline
\end{tabular}

In table 10 , since services are maintained at a certain level, scores at a certain level were received in existing performance evaluations. However, somewhat lower scores were received in the this facility performance evaluations that applied this indicator to consider facility conditions in comparison with the numbers of elapsed years. Efforts to respond to changes in school facilities were not considered at all, and sustainability-related issues were considered as being outside the contracts for which schools should be responsible.

Pilot tests were conducted on the performance evaluation indicator. Based on the results, it was found that in most of educational facility in BTL projects, educational facilities cared about the service to be provided under contracts made at the beginning of projects rather than the management of facility conditions, and emphasized only the role of operators and managers before the transfer of control.

Since the extent of performance in comparison with plans and the evaluation of stakeholder satisfaction were similar to the existing indicator, the applicability of the new indicator was judged to be sufficient. However, some opinions held that since facility condition evaluation may involve different subjective views, experts in condition evaluation should be cultivated. The need for detailed plans to use this facility condition evaluation indicator and plans to apply this facility condition evaluation indicator to existing operation performance evaluation systems was apparent.

\section{CONCLUSION}

Educational facility BTL projects facing their fifth year of operation and maintenance have been evaluated in regards to operation performance based on the performance requirements presented in the negotiation process. However, considering the sustainability of educational facilities after operation and maintenance periods of 20 years or more, persons in charge of BTL projects in the education office, as well as educational facility managers, are demanding the introduction of quantitative standards for qualitative items-such as facility status and performance, inspection items, and indicators-along with management that is acceptable for the requirement level. In addition, although various evaluations are conducted for operation and maintenance plans in the project selection stage, problems caused by service quality performance-oriented evaluation are expected in the operation performance evaluation stage.

For this reason, performance evaluation items and indicators in four areas, operational maintenance evaluation, facility performance status evaluation, maintenance subject evaluation, and sustainable change response evaluation, were developed as part of the establishment of an operation performance evaluation system in the educational facility. Contrary to expectations, facility performance status evaluation took a higher weight than operational maintenance evaluation or maintenance subject evaluation. The lowest weights were found in sustainable change response evaluation, despite the fact that the BTL project has been underway for more than 20 years. This is because the sustainability of educational facilities must be considered, but predicting the related changes is difficult.

Moreover, an evaluation model for the indicator of facility performance evaluation presented in 4.4 is suggested to extract factors that influence the operation performance evaluation result and to specify the relationship between factors. Utilizing this weighting analysis of evaluation factors in operation performance evaluation results enables an improvement in the priority selection method, where facility status and change response items in conformance with existing performance requirements are reflected for operation of the performance system.

The utilization plan for the facility performance indicator, from the results of this study, was suggested as follows.

- First, it was considered that more work-oriented management outcome assessment could be expected by utilizing quantified contents of the facility performance indicator reflected in a summary of the existing outcome assessment as an assessment standard for the management outcome assessment.

- Second, this study suggested the introduction of the facility performance indicator at the maintenance VE stage to maintain the level of maintenance management at the optimal demand level, as much as the performance of the facility was reduced.

- Third, this performance evaluation indicator would be used at the time that a business performer transferred the facility to the competent authorities after 20 years of SPC's management.

The indicator of facility performance evaluation suggested in this paper should be taken as an initial step in developing the operation performance evaluation system of education facility BTL projects. Additional studies are required in regards to introducing the maintenance VE system for future operation and maintenance system construction or educational facility BTL projects. 


\section{REFERENCE}

Detail operation guides for Build Transfer Lease project [BTL] facility management., 2009, Public Investment Management Center

Facility management guidebook, 2000, Japan FM promotion communication council, (edition) Korea facility management academy (translation)

BTL project Evaluation and Improvement solution study for school facilities, 2009, Korea Educational Development Institute

Performance requirements of Build Transfer Lease project (BTL) for school facilities, 2009, Gyeonggi-do educational office

Semi-final Report, A study of the construction of the operation performance evaluation system in public educational facility BTL projects with the introduction of facility performance indicator, 2011, Mokwon University

(Date of Submission : 2011.9.20) 